available at URL: https://decentralization.gov.ua/news/4913, accessed on November 04, 2019.

3. Buletsa, N. 2017. Stimulyuvannya socialno-ekonomichnogo rozvitku regionu $\mathrm{v}$ umovah finansovoyi decentralizaciyi [Formation of the local selfgovernment budgets in conditions of fiscal decentralization]. Kyiv, PhD dissertation. [in Ukrainian]

4. Kwon, O. 2002. The Effects of Fiscal Decentralization on Public Spending: The Korean Case. School of Public and International Affairs. Available at: DOI https://doi.org/10.1111/j.0275-1100.2003.02304001.x

5. Quigley, J.M. and Smolensky, Eu. 1994. Modern public finance. Cambridge, Mass.: Harvard University Press.

DOI https://doi.org/10.30525/978-9934-26-045-2-5

\title{
ПУБЛІЧНЕ УПРАВЛІННЯ МІЖРЕГІОНАЛЬНИМИ КЛАСТЕРАМИ ЯК СУЧАСНИЙ ІНСТРУМЕНТ ПОЛІТИКИ РЕГІОНАЛЬНОГО РОЗВИТКУ
}

\author{
Корнієвський С. В. \\ кандидат наук з державного управління, \\ докторант кафедри економіки \\ та регіональної економічної політики \\ Дніпропетровського регіонального інституту \\ державного управління \\ Національної академії державного управління \\ при Президентові України \\ м. Дніпро, Украӥна
}

Виклики сьогодення вимагають модернізації управлінських підходів для вирішення завдань регіонального розвитку. Одним із таких підходів $є$ кластерний підхід, який, хоча і $є$ відносно новим, але вже потребує певного удосконалення та більш широкого використання в процесах формування та реалізації політики регіонального розвитку. В даній роботі розглядаються аспекти публічного управління у сфері створення та діяльності міжрегіональних кластерів.

Зараз і в Європі і світі в цілому традиційна кластерна політика, сформована в основному на «портерівских» моделях і концепціях, себе вичерпує - вона вже не є достатнім драйвером зростання. Потрібна модернізація кластерної теорії і вироблення моделей публічного управління кластерами, адаптованих до умов мінливого світу. Кластери повинні стати універсальним інструментом для розвитку територій. 
Особливого значення в умовах глобалізаційних процесів набуває сприяння органами влади регіонального рівня функціонуванню міжрегіональних виробничих кластерів.

Сьогодні можна впевнено говорити про те, що XXI ст. - це століття розвитку промислового устрою, заснованого на функціонуванні територіальних кластерів. Останні поступово стають одним 3 провідних рушійних чинників еволюції світової економіки і навіть беруть на себе роль іiі локомотивів, яка традиційно відводилась великим підприємствам і холдингам.

Сучасні виробничі та інформаційні технології істотно знижують витрати підприємств і організацій малого бізнесу, асоційованих в кластери, нівелюючи економічні переваги, властиві великим компаніям. Скорочення транспортних витрат, вдосконалення технологій малої розподіленої енергетики створюють додаткові стимули для формування кластерних мереж підприємств, що демонструють високу адаптивність як до нових викликів зовнішнього середовища, так і до вимог покупців. Розвиток кластерів, в свою чергу, стимулює зміну соціальної структури постіндустріального суспільства, що обумовлює появу нових форм організаційної та споживчої поведінки людей.

Для відповіді на питання про те, що таке кластер, нам необхідно зрозуміти, що в силу цілого ряду причин підприємства розподіляються по територіях нерівномірно. У деяких регіонах відбувається не просто концентрація компаній, а виробництво додаткових соціальних благ i економічних вигод через їх синергію і колективні взаємодії. У таких місцях поступово формується територіальний кластер, який представляє собою безліч конкуруючих підприємств та підприємств, які кооперуються один з одним, є компактно локалізованими в певному регіоні i виробляють конкурентоспроможну продукцію. Остання визначає експортну специфіку регіону або специфіку його міжрегіональних економічних зв'язків.

Якщо ще 15-20 років тому багато питань, пов'язаних 3 формуванням кластерів, були дискусійними, а відповідний науковий апарат і управлінський інструментарій були сформовані недостатньо, то зараз можна 3 упевненістю констатувати наявність яскраво оформленої концепції територіального і галузевого розвитку, заснованої на кластерному підході. У світі створені наукові школи, які вивчають територіальні кластери, функціонують кластерні національні обсерваторії.

Піонером в області дослідження регіональних економік i особливостей локалізації підприємств на території є Альфред Маршалл, який проводив аналіз еволюції промислових округів, що розвиваються, в першу чергу, на базі трудових укладів, сімейних $\mathrm{i}$ ремісничих 
форм організації праці, характерних для малих підприємців, які кооперуються [1, с. 256].

У 1970-ті pp. представники нової економічної теорії сформулювали ідеї, пов'язані 3 впливом концентрації регіональних підприємств на загальне економічне зростання, а в 1990-х рр. Пол Кругман запропонував тези нової економічної географії, що пояснює нерівномірність розподілу підприємств і робить акцент на можливостях економічного розвитку агломераційних систем [2].

Майкл Портер в роботі «Конкуренція», доводив зв'язок між конкурентоспроможністю підприємств i їх участю в національних i глобальних ланцюжках цінності (value chain), залученістю в успішно працюючі кластери [3].

Суть сучасного кластерного підходу до регіонального розвитку в контексті міжрегіональної інтеграції полягає в тому, щоб різні зацікавлені особи (стейкхолдери) - бізнес-співтовариство в регіонах, громадські, наукові та освітні організації, регіональні органи влади, фінансові інститути - змогли консолідувати свої зусилля по кооперації великого числа конкуруючих між собою підприємств в міжрегіональний кластер. Передбачається, що успішна кооперація конкурентів стимулює економічне зростання і соціальний розвиток як окремих регіонів, так і країни в цілому.

Ця кооперація може здійснюватися через організацію різних спільних проектів (інфраструктурних, наукових, соціальних, маркетингових), а також розвиток програм державно-приватного партнерства учасників кластера, що буде вимагати від органів влади регіонів, які утворюють спільний кластер, прийняття публічно-управлінських рішень особливого характеру. Такі рішення мають враховувати координацію дій регіональних органів влади щодо посилення конкурентоспроможності на глобальному рівні, концентрації капіталу і ресурсів у пріоритетних сферах виробництва спільних продуктів інтегрованих регіонів. Така координуюча роль державної політики регіонального розвитку сприятиме забезпеченню оптимізації розміщення продуктивних сил у інтегрованих регіонах, вибору технологій, способів ведення виробництва і його обсягів, виробничих $\mathrm{i}$ екологічних стандартів, асортименту та параметрів продукції 3 урахуванням глобальної ринкової кон'юнктури.

Органи державної влади та місцевого самоврядування ряду держав, міжнародні організації використовують кластерний підхід при формуванні та реалізації рішень, пов'язаних 3 комплексним розвитком територій і галузей, формуючи так звані кластерні політики - заходи, що враховують інтереси різних груп і організацій, спрямовані на підтримку зростання територіальних кластерів. 
Завдяки кластерного підходу публічні управлінці можуть взяти на озброєння ідеї і методи, необхідні для переведення економіки в режим ендогенного економічного зростання.

Зараз, у другому десятилітті XXI ст., вже можна говорити про історію розвитку кластерів. У $1990-\mathrm{i} \mathrm{pp}$. акцент в світі робився на кластерних політиках, які є тими чи іншими аспектами промислового прогресу, і кластери в першу чергу розглядалися в контексті еволюції регіональних промислових систем. На початку нинішнього століття акцент поступово почав зміщуватися в бік формування регіональних інноваційних систем (PIC), і кластерна політика стала позиціонуватися як інструмент реалізації національних стратегій інноваційного розвитку, що мають на увазі системні заходи щодо інтеграції в національні економіки укладів і інститутів, що генерують інновації світового рівня.

Сьогодні в рамках науки публічного управління актуалізуються питання розробки нових інструментів реалізації кластерних політик i кластерних ініціатив, формування ефективної стратегії колективних дій органів влади регіонального рівня та інших акторів у сфері регіонального розвитку, яка спрямована на розвиток міжрегіональних кластерів.

Взявши за основу підхід О. Солвелла [4] можна запропоновати наступну структуру міжрегіонального кластера (рис. 1).

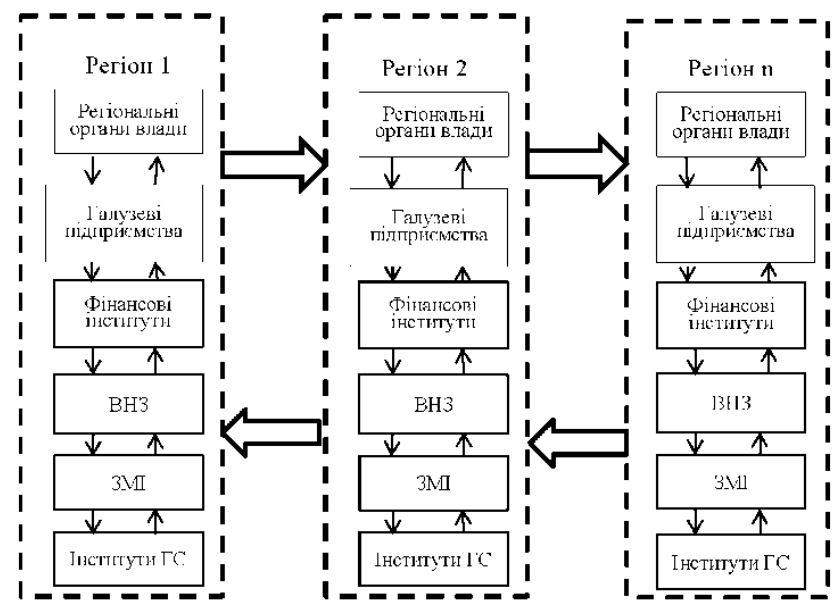

Рис. 1. Основні складові структури міжрегіонального кластера 
Враховуючи наведене можна зробити висновок, що головним кластеротвірним чинником $є$ узгодженість дій регіональних органів влади щодо впровадження політики регіонального розвитку у сфері міжрегіональної інтеграції. Це зумовлює активізацію наукових пошуків у галузі науки публічного управління, спрямованих на удосконалення регіонального розвитку.

\title{
Література:
}

1. Маршалл А. Принципы экономической науки. - М.: Прогресс, 1993. - $594 \mathrm{c}$.

2. Krugman P. R. Geography and Trade. Cambridge, MA: MIT Press, 1991. $-156 \mathrm{p}$.

3. Портер М. Ю. Конкуренция. - М.: Издат. дом «Вильямс», 2005. $-608 \mathrm{c}$.

4. Solvell O. Clusters - Balancing Evolutionary and Constructive Forces. Stockholm: Ivory Tower Pub., 2009. - P. 17.

DOI https://doi.org/10.30525/978-9934-26-045-2-6

\section{ДИФЕРЕНЦІЙОВАНА ІНТЕГРАЦІЯ \\ В ЄС ЯК СПОСІБ ЗАБЕЗПЕЧЕННЯ НАДНАЦІОНАЛЬНОЇ УПРАВЛІНСЬКОЇ СТІЙКОСТІ ПІСЛЯ ВRЕХІТ}

\author{
Кривцова О. М. \\ кандидат наук з державного управління, \\ доиент кафедри глобалістики, \\ євроінтеграції та управління національною безпекою \\ Одеського регіонального інституту державного управління \\ Національної академії державного управління \\ при Президентові України \\ м. Одеса, Украӥна
}

Безперервні дебати щодо диференційованої інтеграції в ЄС отримали новий імпульс, викликаний рішенням британців 23 червня 2016 року залишити об'єднання 28 країн. В результаті ми стали свідками появи діаметрально протилежних прогнозів про наслідки Брекзіту та його вплив на ступінь диференціації в європейському інтеграційному процесі. На одному полюсі цих думок знаходиться 